\title{
Phenylalanine flux and gastric emptying are not affected by replacement of casein with whey protein in the diet of adult cats consuming frequent small meals
}

\author{
Tanya J Tycholis ${ }^{1}$, John P Cant ${ }^{*}$, Vern R Osborne ${ }^{1}$ and Anna K Shoveller ${ }^{2}$
}

\begin{abstract}
Background: Decreasing the rate of protein emptying from the stomach may improve efficiency of utilization of dietary amino acids for protein deposition. Some studies in rats and humans have shown casein to be more slowly released from the stomach than whey protein. To test if casein induces a slower rate of gastric emptying in cats than whey protein, $\mathrm{L}-\left[1{ }^{-13} \mathrm{C}\right]$ phenylalanine (Phe) was dosed orally into 9 adult cats to estimate gastric emptying and whole-body Phe flux.

Results: Concentrations of indispensable amino acids in plasma were not significantly affected by dietary protein source. First-pass splanchnic extraction of Phe was not different between diets and averaged 50\% (SEM =3.8\%). The half-time for gastric emptying averaged 9.9 min with casein and 10.3 min with whey protein, and was not significantly different between diets (SEM $=1.7 \mathrm{~min}$ ). Phenylalanine fluxes were 45.3 and $46.5 \mu \mathrm{mol} /(\mathrm{min} \cdot \mathrm{kg})$ for casein- and whey-based diets, respectively (SEM $=4.7 \mu \mathrm{mol} /(\mathrm{min} \cdot \mathrm{kg})$ ).

Conclusions: In adult cats fed frequent small meals, the replacement of casein with whey protein in the diet does not affect supply or utilization of amino acids. These two milk proteins appear to be equally capable of meeting the dietary amino acid needs of cats.
\end{abstract}

Keywords: Cat, Gastric emptying, Casein, Whey protein, Phenylalanine flux

\section{Background}

Cats are obligate carnivores and require a high level of dietary protein to maintain nitrogen balance, compared to omnivorous and herbivorous species [1]. This high requirement is due to faster rates of catabolism of amino acids. The rate at which dietary protein is emptied from the stomach into the small intestine for absorption may influence the rate of amino acid catabolism and, hence, the ability to meet the cat's high protein requirement. Casein and whey have been designated slow- and fastemptying proteins, respectively, in other species. Daniel et al. [2] reported a mean half-time of $78 \mathrm{~min}$ for gastric emptying of casein suspensions in rats, compared to

\footnotetext{
* Correspondence: jcant@uoguelph.ca

${ }^{1}$ Department of Animal and Poultry Science, University of Guelph, Guelph, Ontario N1G 2W1, Canada

Full list of author information is available at the end of the article
}

21 min for whey. The slower emptying rate of dietary casein may lead to less accelerated and more prolonged delivery of amino acids to peripheral tissues for deposition of body protein [3]. In contrast, the rapid increase in amino acid absorption from whey resulted in significantly greater oxidative losses of indispensable amino acids in humans [3]. However, Calbet and Holst [4] found no differences in gastric emptying of casein vs. whey suspensions in humans, suggesting that the slow vs. fast designation is not consistent. These differences may be a result of the total intake of the proteins, frequency that proteins and accompanying macronutrients are fed, the form in which they are included in the diet, or the processing methods that these proteins are exposed to. Furthermore, oxidative losses of indispensable amino acids may have less of an effect on protein deposition in cats than omnivores because cats typically 
catabolize a large proportion of their dietary amino acid intake regardless of frequency of feeding [5].

To our knowledge, the effects of slow vs. fast proteins have not been investigated in cats. To test if casein induces a slower rate of gastric emptying in cats than whey protein, and thus could be an appealing addition to commercial feline diets, we used orally administered $\mathrm{L}-\left[1-{ }^{13} \mathrm{C}\right]$ phenylalanine (Phe) to estimate emptying rates and whole-body Phe kinetics in adult cats fed casein- and whey-based diets.

\section{Methods}

\section{Cats and housing}

Nine neutered, specific pathogen-free, domestic shorthair cats owned by Procter and Gamble, Inc. ( 5 male, 4 female) were used in this study. Cats were $9.5 \pm 1.2$ years old (mean $\pm \mathrm{SE}$ ) and weighed $5.0 \pm 0.4 \mathrm{~kg}$. Standard physical evaluation by the attending veterinarian of the overall health of all cats was completed prior to the start of the study, and they were all deemed healthy. Cats were identified by name and microchip, and housed in the Procter and Gamble Pet Care, Pet Health and Nutrition Center, Lewisburg, OH, USA. Prior to the beginning of the study, cats were acclimated to group housing in the cat colony that was a controlled environment where cats only had indoor access. The cats were exposed to natural and artificial light (from 0600 to $1800 \mathrm{~h}$ ), indoor environmental temperature was maintained at $22^{\circ} \mathrm{C}$, and rooms were cleaned daily. Cats were fed once daily in individual cages within their group housing room. Once the cats completed their feed they were put back down in the group housing environment and all cats completed their daily allotment of food within 5 hrs. If any food was left after $5 \mathrm{hrs}$, it was weighed and true food intake was calculated. All procedures were reviewed and approved by the P\&G Pet Care Animal Care and Use Committee and in compliance with USDA and AALAC requirements. Reporting of methodology in this manuscript adheres to the ARRIVE guidelines.

\section{Experimental design}

Gastric emptying was estimated by comparing the kinetics of labelled Phe excursion through plasma from an oral versus an IV dose [6]. The method also yields estimates of first-pass extraction by the splanchnic bed, and wholebody flux of Phe. Phenylalanine is a dietary indispensable amino acid for protein synthesis and is not catabolized to any extent except in the liver where it is converted to the amino acid tyrosine, which may be incorporated into body protein or further catabolized in the liver to produce ATP or glucose [7]. Because of its low and contained catabolism and small pool size, labelled Phe has often been used as a tracer for measurements of protein synthesis and turnover in animals [8]. Steady, fed-state conditions were used to simplify the calculations of Phe flux. Intravenous Phe kinetics were measured first, and then cats were assigned to casein- and whey-based diets in a crossover design for the assessment of oral Phe kinetics.

Prior to estimation of IV Phe kinetics, all cats were fed a standard commercial adult diet (Iams Multi-Cat, P\&G Pet Care, Mason, $\mathrm{OH}$ ) at $60 \mathrm{~g} / \mathrm{d}$ once daily at $0700 \mathrm{~h}$ for 7 days. This level of intake historically resulted in no weight change in any of the cats and was therefore used as the metabolizable energy requirement for weight maintenance of the cats on this study since we wanted the cats to maintain, not lose or gain, weight. On day 8 , after an 18 -h fast, Surflo catheters (18 ga $\times 2$ "; Terumo Medical Corp., Somerset, NJ) were inserted into one cephalic vein under Propofol sedation (Hospira Inc., Lake Forest, IL). The daily food allocation was divided into 24 small meals. After two small meals were fed 15 minutes apart, baseline blood samples were collected from the catheter and then a bolus of $12 \mathrm{mg} / \mathrm{kg} \mathrm{BW} \mathrm{L-}\left[1-{ }^{13} \mathrm{C}\right] \mathrm{Phe}\left(99\right.$ atom\% $1-{ }^{13} \mathrm{C}$ ) was administered intravenously (IV) through the catheter and flushed with heparinized saline. Thereafter, cats were fed $1 / 24$ of their daily ration of food every $1 / 2$ hour to maintain a physiological steady state wherein Phe kinetics would not change during its measurement. Blood samples were collected into heparinized tubes approximately 10 , $20,30,45,60,90,120,180,240,300,480,600$, and 720 minutes after the IV bolus. Actual sample times were recorded. Samples were immediately centrifuged at $5000 \mathrm{rpm}$ and plasma was frozen at $-20^{\circ} \mathrm{C}$ for later analysis. Hematocrit was evaluated every $6^{\text {th }}$ sample to ensure that packed cell volume did not diminish. No cats were removed due to a decline in hematocrit.

After the IV Phe study, cats were randomly allocated to isonitrogenous and isocaloric casein- or whey-based diets (Table 1) in a crossover design. The two dry extruded feline diets (Table 1) were made on a twin screw extruder (APV MPF-65, Baker Perkins Limited, United Kingdom) using similar and standard conditioning, extrusion, drying and flavor enhancement processing conditions. Both diets were formulated to meet or exceed Association of American Feed Control Officials (Champaign, IL) recommendations and would be considered "complete and balanced" for adult cats. Cats were maintained on these diets for 23 days, and fed $30 \mathrm{~g}$ at 0700 and $1500 \mathrm{~h}$ daily. On days 21 and 23, 5 and 4 cats, respectively, were subjected to an oral Phe kinetics protocol according to the IV protocol described above, where $12 \mathrm{mg} / \mathrm{kg} \mathrm{BW}$ $\mathrm{L}-\left[1-{ }^{13} \mathrm{C}\right]$ Phe was administered orally by syringe. Cats were subsequently fed the standard diet for $7 \mathrm{~d}$, switched to the opposite experimental diet for 21 and 23 days, and the oral Phe kinetics protocol was repeated. Assignment of cats to sampling on days 21 or 23 remained the same in both periods. 
Table 1 Ingredient and chemical composition of casein- and whey-based diets (as-fed basis)

\begin{tabular}{|c|c|c|}
\hline Ingredients (\%) & Casein & Whey \\
\hline Yellow corn & 37.2 & 35.2 \\
\hline Casein & 20.0 & 0 \\
\hline Whey & 0 & 21.6 \\
\hline Chicken Fat & 9.7 & 9.1 \\
\hline Corn gluten meal & 6.1 & 6.2 \\
\hline Chicken by-product meal & 10.7 & 10.7 \\
\hline Chicken & 5.0 & 5.0 \\
\hline Beet Pulp & 2.4 & 2.4 \\
\hline Chicken digest & 1.4 & 1.4 \\
\hline Dicalcium phosphate & 1.04 & 1.05 \\
\hline Corn grits & 0.95 & 0.96 \\
\hline Brewer's rice & 0.94 & 0.96 \\
\hline Egg & 0.81 & 0.82 \\
\hline Brewer's yeast & 0.76 & 0.77 \\
\hline Sodium bisulphate & 0.76 & 0.77 \\
\hline Potassium chloride & 0.64 & 0.65 \\
\hline Calcium carbonate & 0.64 & 0.65 \\
\hline Sodium chloride & 0 & 0.48 \\
\hline Mineral Premix ${ }^{1}$ & 0.42 & 0.42 \\
\hline Choline chloride & 0.20 & 0.21 \\
\hline Fish oil & 0.20 & 0.20 \\
\hline DL-methionine & 0.12 & 0.12 \\
\hline Vitamin Premix ${ }^{2}$ & 0.09 & 0.09 \\
\hline \multicolumn{3}{|l|}{ Analyzed nutrient contents (as fed) } \\
\hline Metabolizable energy $(\mathrm{MJ} / \mathrm{kg})^{3}$ & 15.5 & 16.1 \\
\hline Dry Matter & 81.3 & 82.6 \\
\hline Fat & 15.4 & 17.1 \\
\hline Crude Fiber & 1.5 & 1.2 \\
\hline Ash & 6.2 & 6.2 \\
\hline $\mathrm{N}$-free extract & 34.5 & 34.0 \\
\hline Crude Protein & 33.7 & 34.0 \\
\hline Arginine & 1.67 & 1.80 \\
\hline Histidine & 0.76 & 0.62 \\
\hline Isoleucine & 1.39 & 1.50 \\
\hline Leucine & 3.34 & 3.41 \\
\hline Lysine & 2.02 & 2.07 \\
\hline Methionine & 0.97 & 1.00 \\
\hline Phenylalanine & 1.54 & 1.15 \\
\hline
\end{tabular}

Table 1 Ingredient and chemical composition of casein- and whey-based diets (as-fed basis) (Continued)

\begin{tabular}{lll}
\hline Tryptophan & 0.46 & 0.58 \\
Tyrosine & 1.33 & 0.95 \\
Valine & 1.74 & 1.72 \\
\hline
\end{tabular}

${ }^{1}$ Mineral Premix contained: 40.4\% Potassium, 38.1\% Chloride, 3500 ppm Copper, 16120 ppm Manganese, 60000 Zinc, 420 ppm lodine, 150 ppm Cobalt.

${ }^{2}$ Vitamin Premix contained: $36300 \mathrm{~K} \mathrm{IU} / \mathrm{kg}$ Vitamin A, $1725000 \mathrm{lU} / \mathrm{kg}$ Vitamin $\mathrm{D}_{3}, 148650 \mathrm{lU} / \mathrm{kg}$ Vitamin E, 22575 ppm Thiamine, 89130 ppm Niacin, 19 200 ppm Pyridoxine, 25935 ppm Pantothenic acid, 2430 ppm Folic acid 189 ppm Vitamin $B_{12}, 5520$ ppm Inositol, 54000 ppm Vitamin C, 540 ppm Biotin, 5940 ppm Riboflavin.

${ }^{3}$ Calculated by using modified Atwater coefficients (1).

\section{Analytical procedures}

Concentrations of $\left[{ }^{13} \mathrm{C}\right]$ Phe in plasma were determined with a triple quadrupole mass spectrometer (API 4000; Applied Biosystems/MDS SCIEX, Concord, ON, Canada) coupled to an Agilent 1100 HPLC system (Agilent, Mississauga, ON, Canada; LC-MSMS), as previously described by Turner et al. [9]. For determination of amino acid concentrations, $25 \mu \mathrm{l}$ plasma were mixed with $200 \mu \mathrm{l}$ methanol in microcentrifuge tubes. These were spun at $13,000 \mathrm{rpm}$ for 5 minutes. The supernatant was dried under a stream of $\mathrm{N}_{2}$, reconstituted in $5 \mu \mathrm{l} 0.1 \%$ formic acid in double distilled water and $0.1 \%$ formic acid in acetonitrile, and subjected to derivatization with phenylisothiocyanate and separation by HPLC $[10,11]$.

Nutrient content of the diets were determined on duplicate samples using the AOAC [12] procedures for dry matter (934.01), crude protein (990.03), amino acids (999.12), acid hydrolyzed fat (954.02), crude fiber (969.33) and ash (942.05). The concentration of nitrogen free extract (NFE) was calculated by difference $(\mathrm{NFE}=100-$ (crude ash + crude protein + acid hydrolyzed fat + crude fiber).

\section{Estimation of isotope kinetics}

Parameters of Phe kinetics and gastric emptying were estimated using methods previously described for dogs [6]. To determine the number of compartments required to simulate Phe elimination from plasma, single $\left(P_{1} e^{-k_{1} t}\right)$ and dual $\left(P_{1} e^{-k_{1} t}+P_{2} e^{-k_{2} t}\right)$ exponential equations were fitted to plasma $\left[{ }^{13} \mathrm{C}\right]$ Phe concentrations following IV dosing $\left(\mathrm{P}_{\mathrm{V}(\mathrm{t})}\right)$ using the Solver function of Microsoft ${ }^{\circ} \mathrm{Office}$ Excel $^{\circ} 2007$ to minimize residual sums of squares. Curve fits were evaluated based on the root mean square prediction error (rMSPE) as a percentage of the mean $\mathrm{P}_{\mathrm{V}(\mathrm{t})}$, calculated as:

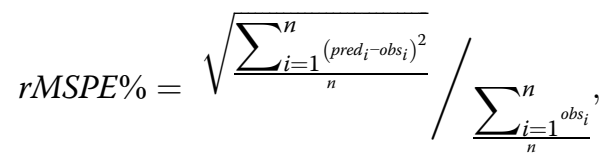

where pred $_{i}$ is the $\mathrm{i}$-th prediction, obs $\mathrm{i}_{\mathrm{i}}$ is the $\mathrm{i}$-th observation, and $\mathrm{n}$ is the number of observations. Because the two 
equations contained different numbers of parameters (q), the decision of which equation best fit the data was based on Akaike's information criterion (AIC), calculated as:

$$
A I C=n \ln \left(\sum_{i=1}^{n}\left(\text { pred }_{i}-o b s_{i}\right)^{2}\right) 2 q .
$$

Phe distribution volume (vol) was calculated from fitted parameter values as:

$$
\text { vol }=I V \text { dose } /\left(P_{1}+P_{2}\right) .
$$

Similar to our previous finding in dogs [6], the analysis identified a two-compartment model as the best fit. Therefore, plasma Phe was assumed to exchange reversibly with a tissue pool (Figure 1). In order to estimate parameters of Phe kinetics from curves of $\left[{ }^{13} \mathrm{C}\right] \mathrm{Phe}$ concentrations following oral dosing $\left(\mathrm{P}_{\mathrm{O}(\mathrm{t})}\right)$ of the tracer, gastric emptying and first-pass extraction of $\left[{ }^{13} \mathrm{C}\right]$ Phe by the splanchnic bed were considered. The oral dosing model assumes first-order, continuous gastric emptying, $100 \%$ post-gastric absorption, and a constant irreversible extraction (ex) of the Phe tracer by the splanchnic bed. Differential equations for the system depicted in Figure 2 are:

$$
\begin{aligned}
& \frac{d G}{d t}=-k_{e m p} G, \\
& \frac{d P}{d t}=k_{e m p} G(1-e x)+k_{P} T-k_{P} P-k_{e l} P,
\end{aligned}
$$

and

$$
\frac{d T}{d t}=k_{P} P-k_{P} T,
$$

where $\mathrm{G}, \mathrm{P}$ and $\mathrm{T}$ are $\left[{ }^{13} \mathrm{C}\right]$ Phe concentrations in gut, plasma and tissues, respectively, $\mathrm{k}_{\mathrm{emp}}$ is the rate constant for gastric emptying, $k_{\mathrm{P}}$ is the rate constant for reversible exchange between plasma and tissue, and $\mathrm{k}_{\mathrm{el}}$ is the rate constant for irreversible elimination from plasma.
The area under $\left[{ }^{13} \mathrm{C}\right]$ Phe concentration curves is related to the dose of $\left[{ }^{13} \mathrm{C}\right]$ Phe injected into the plasma pool and its rate of clearance. Assuming clearance is identical, the ratio of areas under observed $\mathrm{P}_{\mathrm{O}(\mathrm{t})}\left(\mathrm{AUC}_{\mathrm{O}}\right)$ and $\mathrm{P}_{\mathrm{V}(\mathrm{t})}\left(\mathrm{AUC}_{\mathrm{V}}\right)$ curves is equivalent to the ratio of $\left[{ }^{13} \mathrm{C}\right]$ Phe doses introduced into the systemic circulation. Due to the vascular anatomy, entry of orally administered $\left[{ }^{13} \mathrm{C}\right]$ Phe into the systemic circulation requires that it escapes sequestration by gastrointestinal and hepatic tissues of the splanchnic bed, which primarily involves incorporation into secreted proteins and Phe catabolism. Intravenously administered $\left[{ }^{13} \mathrm{C}\right]$ Phe is not subjected to a first-pass splanchnic extraction. Therefore, the value of ex for each cat and diet was estimated from the ratio of $\mathrm{AUC}_{\mathrm{O}}$ to $\mathrm{AUC}_{\mathrm{V}}$ as:

$$
e x=1-{ }^{A U C_{O}} /_{A U C_{V}},
$$

where AUC values were estimated using the trapezoidal method.

To estimate $k_{e m p}, k_{P}$ and $k_{e l}$ for each cat and diet, analytical solutions to differential equations 4, 5 and 6 were obtained with Maple 13 software (Waterloo Maple Inc. Waterloo, Canada) and fitted with Excel ${ }^{\circ}$ Solver to observed $\mathrm{P}_{\mathrm{O}(\mathrm{t})}$ curves. Gastric emptying half-time was calculated as $\ln (2) / k_{\text {emp. }}$. Whole-body Phe flux was estimated as the product of $k_{\mathrm{el}}$, steady-state plasma Phe concentration, and the mean distribution vol estimated from IV Phe kinetics (Eq 3).

\section{Statistical analyses}

Differences between models and diets in goodness of fits and parameter estimates were evaluated by oneway analysis of variance using PROC GLM of SAS (SAS version 9.3; SAS Institute Inc, Cary, NC). Variables that were not normally distributed were natural $\log$-transformed to obtain $P$-values. Values of $P \leq 0.05$ were considered significant and $0.05<P \leq 0.10$ were considered trends.
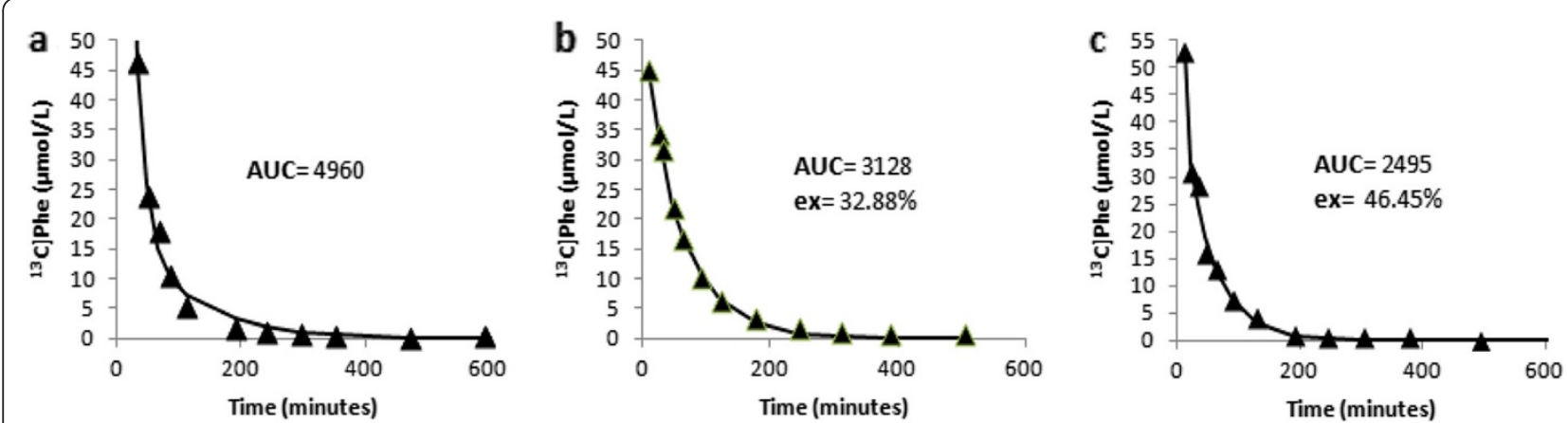

Figure $1\left[{ }^{13} \mathrm{C}\right]$ phenylalanine (Phe) dilution plots. Plasma $\left[{ }^{13} \mathrm{C}\right]$ Phe was measured $(\mathbf{\Delta})$ following $(\mathbf{a})$ intravenous or $(\mathbf{b}, \mathbf{c})$ oral administration of a bolus dose of $\mathrm{L}-\left[1-^{13} \mathrm{C}\right]$ Phe into a cat fed either a (b) casein- or (c) whey protein-based diet. [13C] Phe concentrations were predicted (solid line) with a compartmental model. 
IV dosing model

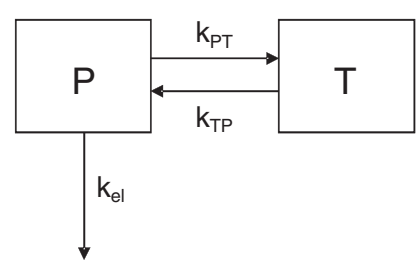

O dosing model

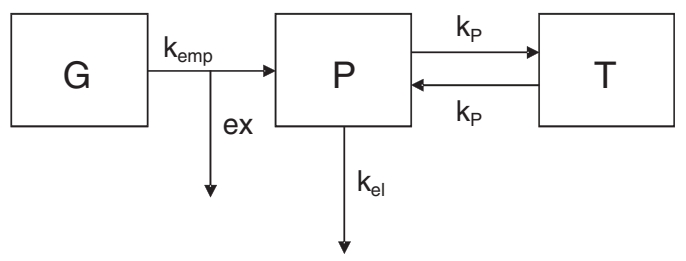

Figure 2 Compartmental models of $\left[{ }^{13} \mathrm{C}\right]$ phenylalanine distribution following intravenous (IV) or oral (O) dosing. Boxes represent state variables, arrows represent flows, $\mathrm{P}$ represents plasma, $T$ represents tissue, $\mathrm{G}$ represents gut, $\mathrm{k}_{\mathrm{p}}$ is the rate constant for reversible exchange between plasma and tissue pools, $k_{e m p}$ is the rate constant for gastric emptying, ex is the first-pass splanchnic extraction, and $k_{e l}$ is the rate constant for irreversible elimination from circulation.

\section{Results}

Throughout intravenous and oral Phe bolus protocols, all cats remained healthy, exhibited full food consumption and maintained their body weights. Due to catheter blockage, IV Phe kinetics were not obtained for one cat and results from this animal were not analyzed. Mean plasma indispensable amino acid concentrations in the last 3 samples collected during 1/2-hourly feeding of the diets (Table 2) were not different between casein and whey $(P>0.31)$, although there was a trend for methionine to be lower $(P=0.09)$ and $P$ he to be higher $(P=0.12)$ with whey. Of the dispensable amino acids in plasma, aspartate

Table 2 Amino acid concentrations $(\mu M)$ in plasma of adult cats

\begin{tabular}{lllll}
\hline Amino acid & Casein & Whey & Pooled SEM & $\boldsymbol{P}$ \\
\hline Alanine & 654 & 678 & 48 & 0.74 \\
Arginine & 133 & 136 & 8 & 0.80 \\
Aspartate & 21 & 38 & 4 & 0.01 \\
Citrulline & 66 & 43 & 8 & 0.09 \\
Cysteine & 28 & 34 & 4 & 0.36 \\
Glutamate & 64 & 88 & 7 & 0.03 \\
Histidine & 134 & 122 & 11 & 0.45 \\
Isoleucine & 90 & 104 & 12 & 0.42 \\
Leucine & 174 & 187 & 13 & 0.50 \\
Lysine & 218 & 210 & 15 & 0.70 \\
Methionine & 139 & 73 & 22 & 0.09 \\
Ornithine & 49 & 56 & 5 & 0.38 \\
Phenylalanine & 87 & 103 & 7 & 0.12 \\
Taurine & 55 & 57 & 9 & 0.87 \\
Tryptophan & 103 & 108 & 15 & 0.83 \\
Tyrosine & 92 & 98 & 14 & 0.78 \\
Valine & 251 & 301 & 33 & 0.31 \\
Indispensable Amino Acids & 1242 & 1123 & 81 & 0.37 \\
Dispensable Amino Acids & 973 & 1005 & 65 & 0.74 \\
Total Amino Acids & 2215 & 2114 & 150 & 0.67 \\
\hline Data are means from 8 to $12 \mathrm{~h}$ & & 515 &
\end{tabular}

Data are means from 8 to $12 \mathrm{~h}$ after initiating consumption of casein- or whey-based diets at 30-min intervals $(n=8)$. and glutamate were higher $(P<0.03)$ on the whey-based diet, while no others were affected $(P>0.36)$.

Modeling the $\mathrm{P}_{\mathrm{V}(\mathrm{t})}$ curves with a dual exponential equation resulted in lower $\operatorname{rMSPE}(P=0.04)$ and AIC $(P<0.01)$ compared with the single exponential equation (Table 3). Lower values indicate better fits. Estimates of Phe distribution volume were not different between equations $(P=0.15)$. A better fit with two exponents indicates two compartments for Phe exchange, which were tentatively identified as plasma and tissue pools. Rate constants for flow from plasma to tissue $\left(\mathrm{k}_{\mathrm{PT}}\right)$ and from tissue to plasma $\left(\mathrm{k}_{\mathrm{TP}}\right)$ were estimated from the dual exponential fits, according to Shipley and Clark [13], as $0.037 \pm 0.008$ and $0.041 \pm 0.016$, respectively. Because these values were not significantly different from each other $(P=0.77)$, it was assumed that a single rate constant $\left(\mathrm{k}_{\mathrm{P}}\right)$ could be used to describe the bidirectional exchange between plasma and tissue (Figure 2). Accordingly, $\mathrm{P}_{\mathrm{O}(\mathrm{t})}$ curves were fit with $k_{\mathrm{P}}$ representing plasma-tissue exchange.

Curves of $\mathrm{P}_{\mathrm{O}(\mathrm{t})}$ were fitted equally well between diets, with no differences in AIC (Table 4). There were no differences between casein- and whey-based diets in $k_{B}, k_{e l}$, or $\mathrm{k}_{\mathrm{emp}}$. First-pass splanchnic extraction of Phe was not different between diets and averaged $50 \%$. Peak $\mathrm{P}_{\mathrm{O}(\mathrm{t})}$ occurred 18.0 and $19.6 \mathrm{~min}$ after oral $\left[{ }^{13} \mathrm{C}\right]$ Phe dosing for casein and whey diets, respectively (data not shown). The half-time for gastric emptying averaged 9.9 min with casein and 10.3 min with whey, but diet treatments were not different from each other. Phenylalanine fluxes were 45.3 and $46.5 \mu \mathrm{mol} /(\mathrm{min} \cdot \mathrm{kg})$ for casein- and whey-based diets, respectively.

Table 3 Fits of 1- and 2-exponent equations to plasma concentrations of $\left[{ }^{13} \mathrm{C}\right] \mathrm{Phe}$

\begin{tabular}{lllll}
\hline & 1-exp & 2-exp & Pooled SEM & $\boldsymbol{P}$ \\
\hline rMSPE (\% of mean) & 13.6 & 2.4 & 3.6 & 0.02 \\
AIC & 79.4 & 40.9 & 5.4 & $<0.01$ \\
Phe distribution volume $(\mathrm{L} / \mathrm{kg})$ & 0.43 & 0.31 & 0.05 & 0.15 \\
\hline
\end{tabular}

Data are means from 8 curves. rMSPE, root mean square prediction error; AIC, Akaike's information criterion; Phe, phenylalanine. 


\section{Discussion}

The timecourse of $\left[{ }^{13} \mathrm{C}\right]$ Phe dilution in plasma after IV injection was best described by reversible distribution into two compartments. The volume of distribution was estimated at $31 \%$ of body weight, which is larger than the extracellular volume of $20 \%$ of body weight estimated by bromide dilution kinetics in cats [14], or $26 \%$ of body weight estimated by isothiocyanate dilution in horses [15]. The larger volume of Phe distribution suggests exchange with intracellular fluid and thus, we tentatively ascribe the second Phe compartment to a tissue pool.

According to the ratio of oral to IV AUC, the first-pass splanchnic extraction of Phe in cats was 50\% of the oral dose. Splanchnic tissues extracted $45 \%$ of an enteral Phe tracer in growing pigs [16]. In adult humans, the first-pass extraction of Phe ranges from 29 to 58\% [17-19]. However, in adult dogs the first-pass extraction of Phe was approximately $20 \%$ [6], which is considerably lower than in cats. Cats are obligate carnivores and their adaptation to high-protein diets may explain why the first-pass extraction of Phe is high [20]. In addition, first-pass extraction of oral amino acids may increase as adults age [21]. In the kinetics study using dogs, the average age was 3 years [6], whereas in our cat study the mean $\pm \mathrm{SE}$ age was $9.5 \pm 1.2$ years. The older age of cats may be an additional reason for higher first-pass splanchnic extraction of Phe in cats compared to dogs.

The loss of half of the absorbed Phe as it traverses the splanchnic bed suggests that Phe is supplied in the diet of adult cats at twice the level necessary for protein synthesis in the body. In support of this conclusion, Rogers and Morris [22] noted that half of the Phe supply to kittens could be removed from a diet containing 1.5\% Phe with no effect on body weight growth. Total amino acid requirements for body weight maintenance and growth are higher than other mammals because of the chronically high level of basal amino acid catabolism [23]. We did not detect any effect of casein compared to whey protein on the splanchnic extraction of Phe, suggesting that casein did not spare indispensable amino acids from hepatic catabolism as in humans [3].

Estimation of gastric emptying from appearance of an oral $\left[{ }^{13} \mathrm{C}\right] \mathrm{Phe}$ dose in plasma is analogous to the acetaminophen absorption test for evaluating liquid-phase gastric emptying [24]. Acetaminophen is poorly absorbed from the stomach and rapidly absorbed in the proximal duodenum so an oral dose appears in plasma according to the rate of delivery from stomach to small intestine [25]. Similarly, Phe is not absorbed from the stomach and absorbed rapidly in the proximal duodenum. Cant et al. [26] derived equations whereby gastric emptying rate constants could be identified from plasma acetaminophen appearance curves, and the same equations were used herein to analyze $\left[{ }^{13} \mathrm{C}\right] \mathrm{Phe}$ appearance in plasma.
Labelled Phe reached its maximum concentration in plasma at $19 \pm 2 \mathrm{~min}$ after oral dosing. Accordingly, the half-time of gastric emptying was estimated to occur at $10 \pm 1.7 \mathrm{~min}$, on average. This average is smaller than the mean half-times of 46 to $67 \mathrm{~min}$ reported for exit of labelled liquids from the cat stomach [26-28] but similar to half-times of 18 to 21 min reported for gastric emptying of suspensions of milk proteins in rats and humans $[2,4]$. Our low estimates are likely a consequence of the small meals which are emptied more rapidly from the cat stomach $[29,30]$. Gastric emptying measurements are usually performed after a test meal representing 50 to $100 \%$ of the daily nutrient intake while we offered only $1 / 24$ of the daily intake with the gastric emptying tracer. The large meal size in gastric emptying studies is used as part of a standardized protocol to allow clinical detection of pathological or pharmacological abnormalities in individuals [24]. Our objective, on the other hand, was to compare amino acid supply from casein- and whey-based diets and, in order to measure amino acid flux, we maintained a non-isotopic steady-state of amino acid concentrations by feeding frequent small meals throughout the day. Although the small meals may have accelerated gastric emptying, there was opportunity to detect differences between diets because, according to our $\mathrm{k}_{\mathrm{emp}}$ estimate of $0.12 / \mathrm{min}, 97 \%$ of the $\left[{ }^{13} \mathrm{C}\right]$ Phe dose was cleared from the stomach in the 30-min interval between meals. Furthermore, this method of "nibbling" is thought to be normal for cats that are free fed and a benefit to maximize digestibility and avoid insulin resistance [31].

Including casein in the diet of frequently fed adult cats did not slow down liquid-phase gastric emptying, which could account for the lack of effect on splanchnic extraction of Phe. Calbet and Holst [4] also found no difference in liquid-phase gastric emptying between casein and whey protein in humans, while Daniel et al.

Table 4 Parameters of Phe kinetics following oral administration of a bolus dose of L- $\left[1-{ }^{13} \mathrm{C}\right] \mathrm{Phe}$

\begin{tabular}{|c|c|c|c|c|}
\hline & \multicolumn{2}{|l|}{ Oral } & \multirow{2}{*}{$\begin{array}{l}\text { Pooled } \\
\text { SEM }\end{array}$} & \multirow[t]{2}{*}{$P$} \\
\hline & Casein & Whey & & \\
\hline rMSPE (\% of mean) & 10.9 & 12.4 & 3.0 & 0.74 \\
\hline $\mathrm{AIC}$ & 42.4 & 42.6 & 7.4 & 0.91 \\
\hline$k_{p}(/ \min )$ & 0.039 & 0.063 & 0.015 & 0.36 \\
\hline $\mathrm{k}_{\mathrm{el}}(/ \mathrm{min})$ & 0.027 & 0.027 & 0.003 & 0.74 \\
\hline$k_{e m p}(/ \min )$ & 0.115 & 0.127 & 0.053 & 0.99 \\
\hline first-pass extraction (\%) & 51.3 & 48.5 & 3.8 & 0.64 \\
\hline gastric emptying half-time (min) & 9.9 & 10.3 & 1.7 & 0.87 \\
\hline Phe flux $(\mu \mathrm{mol} /(\mathrm{h} \cdot \mathrm{kg}))$ & 45.3 & 46.5 & 4.7 & 0.85 \\
\hline
\end{tabular}

Data are means from 8 cats per treatment. rMSPE, root mean square prediction error; AIC, Akaike's information criterion; $k_{p}$, rate constant for reversible exchange between plasma and tissue pools; $\mathrm{k}_{\mathrm{el}}$, rate constant for irreversible elimination from circulation; $k_{e m p}$ gastric emptying constant. 
[2] reported an increase in half-time from 21 to $78 \mathrm{~min}$ in rats given casein instead of whey protein. Hall et al [32] found that a liquid casein meal stimulated faster release of acetaminophen from the stomach of humans compared to liquid whey protein. Therefore, the designation of casein as slow and whey protein as fast is not consistent across studies or species.

Phenylalanine flux was not affected by substituting casein for whey protein in the diet. Flux represents entry of Phe into the plasma pool from post-splanchnic absorption plus breakdown of proteins in the body, or exit from the plasma pool to whole-body protein synthesis plus catabolism, which is primarily hepatic. Assuming $90 \%$ digestibility and 50\% first-pass splanchnic extraction, entry rates of Phe from the diet were 41 and $31 \mu \mathrm{mol} /(\mathrm{h} \cdot \mathrm{kg})$ for casein and whey treatments, respectively, equivalent to 90 and $67 \%$, respectively, of the flux estimates. These proportions are overly high, as intake normally accounts for 25 to $40 \%$ of flux in various species [33], and was 50\% in adult cats [34]. Phenylalanine flux was estimated from $\mathrm{k}_{\mathrm{e}}$, Phe concentration in plasma, and Phe distribution volume, so imprecision in any one of these variables could contribute to the underestimation. $\left[{ }^{13} \mathrm{C}\right]$ Phe curves were well fitted with a monoexponential decline yielding $\mathrm{k}_{\mathrm{el}}$ estimates that exhibited low variability across cats and diets. Thus, $\mathrm{k}_{\mathrm{el}}$ estimation does not appear suspect, nor do the Phe concentrations in plasma which are similar to previously reported values [35]. The distribution volume estimate of $0.31 \mathrm{~L} / \mathrm{kg}$ is similar to values of 0.34 and $0.47 \mathrm{~L} / \mathrm{kg}$ estimated for leucine distribution in humans [36,37], but is approximately 5 times smaller than the methionine distribution volumes of 1.2 to $1.8 \mathrm{~L} / \mathrm{kg}$ estimated in rats [38]. If Phe distribution volume were $1.2 \mathrm{~L} / \mathrm{kg}$, the flux estimate would be $178 \mu \mathrm{mol} /(\mathrm{h} \cdot \mathrm{kg})$, on average.

\section{Conclusions}

While there is uncertainty about the true Phe distribution volume and Phe flux, it does not affect the conclusion that diet had no effect on Phe flux. This finding is consistent with the lack of effect on liquid-phase gastric emptying, first-pass splanchnic extraction of Phe, and indispensable amino acid concentrations in plasma. In adult cats fed frequent small meals, the replacement of casein with whey protein in the diet does not affect systemic supply or utilization of amino acids. These two milk proteins appear to be equally capable of meeting the amino acid needs of cats. Further research should investigate other purported benefits of casein and whey, such as its effects on carbohydrate metabolism and palatability [39].

\section{Competing interests}

AKS is an employee of The Procter and Gamble Co. that funded the study.

\section{Authors' contributions}

TJT analyzed the data, conducted the model fits, and drafted the manuscript. JPC helped with study design, modelling and data analysis, and editted the manuscript. VRO participated in data analysis and revision of the manuscript. AKS conceived the study, supervised treatments and sample collection, collated data and editted the manuscript. All authors read and approved the final manuscript.

\section{Acknowledgements}

The authors would like to thank staff at the Pet Health and Nutrition Center, P\&G Pet Care: Amy Prosser, Cynthia Lanman, Dawn Spangler, Elizabeth Flickinger, and Nathan Fastinger, for their help during the collection periods. The study was funded by The Procter and Gamble Co.

\section{Author details}

${ }^{1}$ Department of Animal and Poultry Science, University of Guelph, Guelph, Ontario N1G 2W1, Canada. ${ }^{2}$ Procter and Gamble Co., Pet Care, Lewisburg, $\mathrm{OH}$ 45338, USA.

Received: 2 December 2013 Accepted: 29 July 2014

Published: 12 August 2014

\section{References}

1. NRC: Nutrient Requirements of Dogs and Cats. Washington, DC: The National Academies Press; 2006.

2. Daniel $H$, Vohwinkel $H$, Rehner $G$ : Effect of casein and $\beta$-casomorphins on gastrointestinal motility in rats. J Nutr 1990, 120:252-257.

3. Boirie $Y$, Dangin $M$, Gachon $P$, Vasson M-P, Maubois J-L, Beaufrère B: Slow and fast dietary proteins differently modulate post prandial protein accretion. Proc Natl Acad Sci USA 1997, 94:14930-14935.

4. Calbet JAL, Holst JJ: Gastric emptying, gastric secretion and enterogastrone response after administration of milk proteins or their peptide hydrolysates in humans. Eur J Nutr 2004, 43:127-139.

5. Rogers QR, Morris JG, Freedland RA: Lack of hepatic enzymatic adaptation of low and high levels of dietary protein in the adult cat. Enzyme 1977, 22:348-356.

6. Gooding MA, Cant JP, Pencharz PB, Davenport GM, Atkinson $J \mathrm{~L}$, Shoveller AK: Oral and intravenous $L-\left[1-{ }^{13} \mathrm{C}\right]$ phenylalanine delivery measure similar rates of elimination when gastric emptying and splanchnic extraction are accounted for in adult mixed hounds. J Anim Physiol Anim Nutr 2013, 97:181-189.

7. Coffee CJ: Metabolism. Raleigh, NC: Hayes Barton Press; 1999.

8. Garlick PJ, McNurlan MA, Preedy VR: A rapid and convenient technique for measuring the rate of protein synthesis in tissues by injection of $[3 \mathrm{H}]$ phenylalanine. Biochem J 1980, 192:719-723.

9. Turner JM, Humayun MA, Elango R, Rafii M, Langos V, Ball RO, Pencharz PB: Total sulfur amino acid requirement of healthy school-age children as determined by indicator amino acid oxidation technique. Am J Clin Nutr 2006, 83:619-623.

10. Bidlingmeyer BA, Cohen SA, Tarvin TL: Rapid analysis of amino acids using pre-column derivatization. J Chromatogr 1984, 336:93-104.

11. Heinriksson RL, Meredith SC: Amino acid analysis by reverse phase high performance liquid chromatography: precolumn derivatization with phenylisothiocyanate. Anal Biochem 1984, 36:65-74.

12. AOAC: Official Methods of Analysis. 16th edition. Washington DC: AOAC Inc; 2000.

13. Shipley RA, Clark RE: Tracer Methods for In Vivo Kinetics. New York: Academic Press; 1972.

14. Elliott DA, Backus RC, Van Loan MD: Extracellular water and total body water estimated by multifrequency bioelectrical impedance analysis in healthy cats: a cross-validation study. J Nutr 2002, 132:1760S-1762S.

15. Kohn CW, Muir WW, Sams R: Plasma volume and extracellular fluid volume in horses at rest and following exercise. Am J Vet Res 1978, 39:871-874.

16. Stoll B, Burrin DG, Henry J, Jahoor F, Reeds PJ: Phenylalanine utilization by the gut and liver measured with intravenous and intragastric tracers in pigs. Am J Physiol 1997, 273:G1208-G1217.

17. Biolo G, Tessari P, Inchiostro S, Bruttomesso D, Fongher C, Sabadin L, Fratton MG, Valerio A, Tiengo A: Leucine and phenylalanine kinetics during mixed meal ingestion: a multiple tracer approach. Am J Physiol 1992, 262:E455-E463. 
18. Kriengsinyos W, Wykes $L$, Ball RO, Pencharz PB: Oral and intravenous tracer protocols of the indicator amino acid oxidation method provide the same estimate of the lysine requirement in men. J Nutr 2002, 132:2251-2257.

19. Matthews DE, Marano MA, Campbell RG: Splanchnic bed utilization of leucine and phenyalanine in humans. Am J Physiol 1993, 264:E109-E118.

20. Eisert $R$ : Hypercarnivory and the brain: protein requirements of cats reconsidered. J Comp Physiol B 2011, 181:1-17.

21. Volpi E, Mittendorfer B, Wolf SE, Wolfe RR: Oral amino acids stimulate muscle protein anabolism in the elderly despite higher first-pass splanchnic extraction. Am J Physiol 1999, 277:E513-E520

22. Rogers QR, Morris JG: Essentiality of amino acids for the growing kitten. J Nutr 1979, 109:718-723.

23. Green AS, Ramsey JJ, Villaverde C, Asami DK, Wei A, Fascetti AJ: Cats are able to adapt protein oxidation to protein intake provided their requirement for dietary protein is met. J Nutr 2008, 138:1053-1060.

24. Wyse CA, McLellan J, Dickie AM, Sutton DGM, Preston T, Yam PS: A review of methods for assessment of the rate of gastric emptying in the dog and cat: 1898-2002. J Vet Intern Med 2003, 17:609-621.

25. Clements JA, Heading RC, Nimmo WS, Prescott LF: Kinetics of acetaminophen absorption and gastric emptying in man. Clin Pharmacol Therap 1978, 24:420-431.

26. Cant JP, Walsh VH, Geor RJ: Obtaining information on gastric emptying patterns in horses from appearance of an oral acetaminophen dose in blood plasma. In Nutrient Digestion and Utilization in Farm Animals: Modelling Approaches. Edited by Kebreab E, Dijkstra J, Bannink A, Gerrits WJJ, France J. Wallingford: CABI Publishing; 2006:69-83.

27. Gould RJ, Fioravanti C, Cook PG, Solomon HF: A model of gastric emptying in cats shows solid emptying is promoted by MK-329: a CCK antagonist. J Nucl Med 1990, 31:1494-1499.

28. Willson BS, Bushnell D, Keshavarzian A: The effect of acute and chronic ethanol administration on gastric emptying in cats. Dig Dis Sci 1990, 35:444-448.

29. Costello M, Papasouliotis K, Barr FJ, Gruffydd-Jones TJ, Caney SMA: Determination of solid- and liquid-phase gastric emptying half times in cats by use of nuclear scintigraphy. Am J Vet Res 1999, 60:1222-1226.

30. Goggin JM, Hoskinson JJ, Butine MD, Foster LA, Myers NC: Scintigraphic assessment of gastric emptying of canned and dry diets in healthy cats. Am J Vet Res 1998, 59:388-392.

31. Mugford RA, Thorne C: Comparative studies of meal patterns in pet and laboratory housed dogs and cats. In Nutrition of the Dog and Cat. Edited by Anderson RS. UK: Pergamon Press Oxford; 1980:3-14.

32. Hall WL, Millward DJ, Long SJ, Morgan LM: Casein and whey exert different effects on plasma amino acid profiles, gastrointestinal hormone secretion and appetite. Br J Nutr 2003, 89:239-248.

33. Obled C, Arnal M: Age-related changes in whole-body amino acid kinetics and protein turnover in rats. J Nutr 1991, 121:1990-1998.

34. Russell K, Lobley GE, Millward DJ: Whole-body protein turnover of a carnivore, Felis silvestris catus. Br J Nutr 2003, 89:29-37.

35. Heinze $C R$, Larsen $J A$, Kass PH, Fascetti AJ: Plasma amino acid and whole blood taurine concentrations in cats eating commercially prepared diets. Am J Vet Res 2009, 70:1374-1382.

36. Collins JE, Umpleby AM, Boroujerdi MA, Leonard JV, Sonksen PH: Effect of insulin on leucine kinetics in maple syrup urine disease. Pediatr Res 1987, 21:10-13.

37. Jouvet P, Hubert P, Saudubray JM, Rabier D, Man NK: Kinetic modeling of plasma leucine levels during continuous venovenous extracorporeal removal therapy in neonates with maple syrup urine disease. Pediatr Res 2005, 58:278-282.

38. Hasegawa H, Shinohara Y, Akahane K, Hashimoto T: Direct detection and evaluation of conversion of D-methionine into L-methionine in rats by stable isotope methodology. J Nutr 2005, 135:2001-2005.

39. Eller LK, Reimer RA: Dairy protein attenuates weight gain in obese rats better than whey or casein alone. Obesity 2010, 18:704-711.

\section{doi:10.1186/s12917-014-0177-8}

Cite this article as: Tycholis et al:: Phenylalanine flux and gastric emptying are not affected by replacement of casein with whey protein in the diet of adult cats consuming frequent small meals. BMC Veterinary Research 2014 10:177.

\section{Submit your next manuscript to BioMed Central and take full advantage of:}

- Convenient online submission

- Thorough peer review

- No space constraints or color figure charges

- Immediate publication on acceptance

- Inclusion in PubMed, CAS, Scopus and Google Scholar

- Research which is freely available for redistribution

Submit your manuscript at www.biomedcentral.com/submit
() Biomed Central 